\title{
CONTRIBUTIONS OF BRAZILIAN PROJECT PIBID TO PRE-SERVICE CHEMISTRY TEACHERS' EDUCATION IN LOCO
}

\author{
Valéria Campos dos Santos, Luanna Gomes de Gouvêa, \\ Agnaldo Arroio \\ Faculty of Education, University of São Paulo, São Paulo, Brazil
}

\begin{abstract}
Through initiatives of the Brazilian government, undergraduate students are taking the opportunity to experience in practice the challenges of being a teacher, as well as helping to improve education in public schools. One such initiative is the program PIBID (Programa Institucional de Bolsas de Iniciação à Docência - Scholarship Program for teaching' Initiation) which addresses the relationship between school and university favors the exchange of experiences. This paper presents the contributions of chemistry subproject PIBID at USP (University of São Paulo) for pre-service chemistry teachers' students for competent use of visual tools in teaching chemistry. For a qualitative research, were used questionnaires and interviews with pre-service teachers who were participating of the PIBID on the second half of 2012. By the outcomes can be seen the participants' interest about the program, which shows the importance of learning to teach chemistry, leading students visualize the content. Furthermore, it was noticeable that the PIBID changed the viewpoint of the project participants about the teaching career, now they are able to experience other forms of action, re-thinking about the traditional method of teaching. Still, according to the outcomes, pre-service chemistry teachers' students stressed the importance of PIBID on filling gaps of pre-service teacher training programs, facilitating the access to schools and preparing them to act professionally with a more concise theoretical baggage.
\end{abstract}

Key words: PIBID, teacher education, teaching practice.

\section{Introduction}

The training of teachers for the exercise of its function as an educator has been increasingly studied by many researchers in the field of science education (Dori and Barnea, 1997; Chewprecha, Gardner and Sapianchai, 2006; Hampel, 2009; Chien et al., 2012). These studies have been of utmost importance to a greater education of teachers, who now have access to a wide variety of methodologies that favor the formation of well-prepared and active teachers. This training has been bringing differentiated advantages for teachers, school, university students and society.

For the training of acting teachers is necessary they have the ability to create, plan and prepare their own activities. When pre-service teacher students develop their meth- 
odologies, apply and evaluate their performance, they develop the ability to reflect on their practice becoming critical and in constant learning (Zeichner, 1993). For teacher performance occurs effectively, is needed training programs that enable in-service teachers enhance their practice knowing new methodologies and allowing pre-service teachers to live a practical experience with application of different methodologies letting them to a concrete formation, closer to reality.

An initiative to several improvements in teacher education is the PIBID (Scholarship Program of Initiation to Teaching), which began in 2007 as an initiative of the Brazilian Ministry of Education (MEC). This project aims to training pre-service teachers and improves education in public schools. The program PIBID from the Brazilian agency CAPES (Coordenação de Aperfeiçoamento de Pessoal de Nível Superior - Coordination for the Improvement of Educational Staff) provides grants for initiation to teaching for pre-service teachers students. So, they, as part of training, must act in public schools in loco with low grades in ENEM (Exame Nacional do Ensino Médio - National High School Exam) and IDEB (Índice de Desenvolvimento da Educação Básica - Development Index Basic Education). Currently, 195 Brazilian universities are participating in the project, working in about 4000 Brazilian public schools developing 288 different projects, reaching a number of almost 50,000 grants awarded to coordinators, supervisors (in-service teachers) and scholars (pre-service teacher students) (Brazil, 2012). The project aims to facilitate contact of pre-service teachers to schools providing training in the reality of the classroom in loco.

This project encourages the relationship School-University, enabling students and teachers in public schools have access to different methodologies, and allowing preservice teachers to witness and try to deal with the reality of schools, putting into practice the theories studied at university. Moreover, favors the exchange of experiences between pre-service teachers, researchers and in-service teachers.

The PIBID covers various areas of knowledge; in this paper it will be addressed the area of chemistry in the specific case of the University of São Paulo (USP).

The Brazilian universities have different subprojects within the PIBID. In the case of the University of São Paulo, the subproject PIBID of chemistry has worked with the use of visualizations in schools. According to Ferreira (2010), visualization spans nonverbal representation and are used as a way to facilitate understanding of the invisible as atoms, molecules, particles, among others. Within this perspective, the PIBID of USP aims improve teacher training for the use of visual tools. For this, has used the method of production of teaching and learning sequences (TLS), which are constructed collectively between with pre-service chemistry teacher student and in-service chemistry teacher. Thus it is intended that the pre-service teachers are prepared to teach and that the in-service teachers update their practice, both grounded by research in chemical education.

The importance of using visual tools can be justified because the chemistry works with the invisible, these tools can facilitate understanding of chemical interactions at macroscopic, microscopic and symbolic level allowing students to move between these levels facilitating the learning of chemistry concepts (Barnea \& Dori, 2000). 
Currently there are several visual tools such as schematics, diagrams, images, simulators and many other tools that began to obtain a space important and fundamental to the construction of knowledge. Despite the importance of these tools, these often fail to be used in schools due to lack of preparation of teachers to deal with these methods. According to Treagust and Chandrasegaran (2009), teachers worry more about teaching how to solve mechanical chemistry problems than teaching on the particles involved in the reactions, leaving students "lost" about the dynamics of chemical interactions.

Assist teachers in the use of technological tools has been a challenge because most of them, despite knowing about these tools, do not know how or when to use them. Teachers are also increasingly facing students included in technology, due to the constant increase in the access to computers and the Internet, allowing students access to a world of diverse information. Because of this the teachers should have foundation to teach students how to filter information from the internet and the media in general, encouraging them to be critical. Furthermore, students should be encouraged to use the technological tools at home, seeking knowledge, knowing where they can find answers to your questions and knowing how to use these tools for their learning.

Given the above, the PIBID chemistry subproject of USP brings in its project the proposal to prepare pre-service teachers for the use of visual tools, promoting training activities and assisting in the preparation, implementation and evaluation of teaching sequences covering the visualization on the teaching of chemistry.

Therefore, this study aims to show the contribution of the USP subproject PIBID of chemistry for pre-service chemistry teacher students' knowledge about teaching theories, use of visualization at teaching chemistry and training them to teaching practice.

\section{Methodology of Research}

The PIBID subproject of chemistry started its activities at USP on the second semester of 2012. As mentioned above, this subproject aims to promote chemistry education based on theories about visualization and the use of visual resources to help students understand chemistry for complete. Currently, the project has been coordinated by one professor of the Faculty of Education, USP. It includes 12 pre-service chemistry teacher students and 2 public high school in-service chemistry teachers, which receive a scholarship to participate of the project. Post-graduate students act as supports for the preservice chemistry teacher students. The project is being developed through a partnership between the University of São Paulo and a public school in the city of São Paulo, Brazil.

The activities to be developed on the subproject, aims improve the pre-service and in-service chemistry teacher training for the use of visualizations at teaching; contribute to the collaborative production, among pre-service chemistry teacher students and high school teachers, of didactic sequences supported by visual tools; provide training to pre-service teachers with emergent themes of the researches on science education; provide to in-service teachers update their practice based on emergent themes of the researches on science education; and extend the partnership University-Public School as 
an appropriated environment to teacher training, linking theory and practice aiming improve science education.

Throughout the project the pre-service chemistry teacher students have had a theoretical training on theories related to visualization, representational levels, modelling, multimodality, etc. (Barak, Ashkar \& Dori, 2011; Hofstein \& Lunetta, 2004; Jewitt et al., 2001; Johnstone, 1993, 2000; Justi, 2006). In these weekly trainings the students get involved in group discussions that was helpful for both, the reflection about their future practice as a teacher and the practice of preparing the activities developed at a public school.

After the theoretical training, the pre-service chemistry teacher students have performed an evaluation about the use of visual tool at the public school they were going to execute the project, as well as the prior knowledge and difficulties that the high school students present. Based on the earlier analysis, pre-service chemistry teacher students produced teaching and learning sequences (TLS) supported by visual tools and applied these sequences to the high school students.

Seeking to investigate the development of the pre-service chemistry teacher students, they were monitored during the process of discussion, preparation and application of the TLS activities at school. A questionnaire was also applied aiming to know their initial objectives about the project. After their involvement at school, their viewpoints about the project and the experience they have lived were collect by interviews. At this study it is discussed the results of this action research about the PIBID project focusing some points: pre-service chemistry teacher students' expectations when joined the project; changing of perspectives about chemistry education; PIBID as a way to prepare them to teaching practice; PIBID as a way to fill the gaps of the teacher training programs. The action research was chosen for being suitable to this research, since in this process the researcher enters a real world situation and aims both to improve it and to acquire knowledge (Checkland \& Holwell, 1998).

\section{Results of Research and Discussion}

Based on the content analysis (Bardin, 1977) of answers obtained from questionnaires and interviews, it could observes some viewpoints the pre-service chemistry teacher students present about the PIBID project, their changing of perspectives after the work and how the project prepare to the future career as a teacher.

\section{Pre-service Chemistry Teacher Students' Expectations when Joined the Project}

Before the students started the activities at the project, they were asked about their expectations. It was consciousness about the necessity of some students of the scholarship the project provides; two of these have told that the scholarship was a big decoy to join the project. However, despite the scholarship, all the students joined the project with a primary goal: learn about the teacher practice. 
The answers obtained at this question can be organized in two main categories: learn about some teaching methods and techniques; learn about the utilization of visual tools to teach chemistry. Some answers given by these students are showed below.

"I have seen in this project an opportunity to complement my theoretical education about teaching through the teaching practice."

"I believe I can learn new teaching methods and improve the ones I already have. I really want to learn and teach others."

"Improve my knowledge to better explain chemistry contents, using properly the visual tools to a good understanding of my future students."

"The learning, as a docent, to the critical use of visual tools and the practical experience inside the classroom."

In general, all the answers were related to the importance of the knowledge about how to teach, that is, how to apply theories and methodologies learned at university to the practice of teaching. These pre-service teachers expect to learn with the group and at the practice, as stated by Schön (1991), who emphasize that people learn best through active involvement and by thinking about and articulating what they have learned. This conception of learning contributes to teachers' development and encourages them to involve themselves as learners.

The students concern in learn about the use of visual tools to teach chemistry is an admirable attitude, since some researches showed that, in general, teachers doesn't use or can't work correctly with visual tools (Aksela \& Lundell, 2008; Savec et al., 2006). In response to these teachers' difficulties in using visual tools, trainings are being developed in order to prepare teachers to use these tools, and have been showing positive outcomes at teachers' practice (Dori \& Barnea, 1997, 2000).

When asked if the project is filling their needs, all the students answered that it is filling their needs mainly on the theoretical and practical knowledge, "it is helping at the construction of my knowledge, about what is my role at a classroom, how I can work with the theories at classroom". Some of them have emphasized the opportunity the project brings to learn in practice and apply the theories they learn at university in high school classes, "it is showing me another view, it is showing that is possible to apply what we learn at university", "I'm learning in practice how to effectively work, how to solve problems in a classroom". Some also mentioned the importance to learn about visualization, "I'm learning to teach the contents on a visual way". 


\section{Changing of Perspectives about Chemistry Education}

After some months of activities, the pre-service chemistry teacher students stated that the project has helped them to build new perspectives about the teaching of chemistry. This changing of perspectives has shown the contribution of the PIBID project to a greater appreciation and awareness about the teacher career.

Some of them joined the project intending that the project would help them with their internal conflicts about the teacher career. These students doesn't join the course intending to be a teacher, or had doubts about being or not a teacher, and expected that the experience could help them solve their concerns. After some months in the project, these students changed their conceptions about the teacher career and are more likely to be a teacher.

"I'm really not sure if I'll be or not a teacher, but each time more I want to be a teacher."

"I will not give up, I want to be a teacher, I want to act in the education field and the project is surely helping me to keep going."

"I have good perspectives to start to teach."

Another part of them joined the project because they like education and they want to be teachers, but they kept some romantic conceptions about teacher practice. After some months in the project, the students could see that is not so easy to be a teacher, this career have many problems that limit their actions. Thus, the PIBID have been preparing them to become teachers, now they know the problems and limitations of the teacher practice and can be prepared to face these problems.

"I've entered here with a dream to be a teacher, for the possibility to transform the individual. Today I believe that it could happen, but I also know about the problems and limitations of all of it. So, today I'm more conscious about the teacher career, I know the problems and I want to specialize in these problems to help my future students."

"In general, the PIBID have shown me that teaching is a hard task, that requires discernment and consciousness."

Two of them reported that until beginning the activities of the project, the traditional way of teaching was the only one they used to know, or the one they believed to be the best way to teach. Now, they have knowledge about different ways to teach and recognize new possibilities to teach chemistry.

"It has totally changed, because before the project I didn't could see another method to teach than the method my high school teacher used to use, that is, the 
method that the student has no chance to expose their doubts, questions or contributions, just teacher can talk at class."

"I've never learned about constructivism. When I arrived here and learned about new perspectives of teach it was a shock for me, because I've never had a teacher with these perspectives, they were all traditional. I liked a lot and I intend to act at this new perspective."

\section{PIBID as a Way to Prepare Pre-Service Chemistry Teacher Students to Teaching Practice}

When asked about what is their opinion about the PIBID as a way to prepare preservice chemistry teacher students to teach, the students interviewed focused on the teacher practice, the opportunity the project gives to pre-service chemistry teacher students learn how to teach, applying in practice what they learn at university, even before they become a teacher. These students see the PIBID as a complementation for the chemistry course.

"It is an opportunity to pre-service chemistry teacher students to be in a classroom, a real classroom with real students, not the idealized student created at our classes at university... The PIBID provides this, and it makes difference at teacher training. "

"I've seen that it is not necessary to be graduated to acting in class for the first time, you can already have the experience to teach and when you become a teacher, you will have experience in class."

"Only in a classroom, just acting, you will see the problems of your practice, you will evaluate what is wrong and what is right, in what aspect you can improve your teaching."

When referring specifically to the PIBID of chemistry they are participating, some students mentioned the practice of teaching, as cited above. But many of them revealed have learned a lot about the theories of visualization; they believe these theories can help them in their future practice as a teacher. Once asked about what they have noticed at the project they are participating that prepares them to act as a teacher, the students answered that:

"A critical role I've learned is how you will transform all that theory, teaching philosophies, objectives, class planning on teaching practice. After, how you will evaluate the students learning to give continuity to your teaching planning." 
"Totally at the question of the visualization theories, get away from the expositive classes, use videos, pictures and experiments at class. These are things that really get marked. I've learned how I can do this."

"I think this field of visualization very interesting, because many people have difficulties with this, because chemistry is an abstract subject. This aspect of the project, the theories of visualization contribute a lot to the chemistry teaching."

One student revealed that these pre-service chemistry teacher students are learning to be researchers while acting as teachers. They have learned that the theories could help in some problems at teaching.

"I've seen that when we feel with lack of some knowledge we have to seek this knowledge either reading or learning with others, like group discussions, we see ideas that we haven't think about before, it is very cool."

\section{PIBID as a way to fill the gaps of the graduation}

The main concern of the pre-service chemistry teacher students is about the gaps the graduation course presents, mainly about the lack of practical experiences. The Brazilian graduation courses that prepare students to become teachers just offer to students the opportunity to experience the practice of teaching by means of traineeships, where they get in a classroom and watch the class of a high school teacher, they could, sometimes, help the teacher in activities with students or give classes with the supervision of the high school teacher. However, most often the pre-service chemistry teacher students just watch the class, as the high school students do, and don't have the chance to apply their theoretical knowledge on practice.

When asked about how PIBID can help them to fill the gaps of the graduation course, the students emphasized the opportunity the project gives them to learn at practice, to act as teachers and see the real situation of the Brazilian public education.

"This project is carrying me to reality; I'm in a public school, knowing a reality that was very distant to me. Know how to work with these students, understand that they have had different experiences and are not so open to this education, to knowledge; different to what the graduation teachers teach to us, but we see that we have to seduce them to knowledge."

"The project shows us the practice of teaching, we saw that this practice is difficult, but it is possible to make the students participate and, at the same time, you get knowledge about what you have to do."

"The project gives us the practical part, that is what is missing in the graduation course, I think graduation has a lot of theory and, even when we are in 
traineeships, we are very limited, we don't have many liberty to act as teachers."

Some students still emphasized the opportunity to work in group that PIBID gives them and the graduation doesn't giving. According to these students, the group interaction puts them in contact with other viewpoints, from people that are also interested in education.

"The interaction in a group helps us when we have some difficulties, the ones that have more ability can help the ones with difficulties, they try to put their viewpoints and I think it contributes to our knowledge."

"At some graduation classes many people are not interested in education. Here, at the project, everybody is interested and it is not because of the scholarship. The students like PIBID and listen to this people that enjoy education help me to be interested and construct my knowledge."

\section{Discussion about the Relationship between Theory and Practice}

The students' statements (shown above) about the contribution of the project PIBID to their knowledge as pre-service teachers have converged to a main point: the relationship between theory and practice. These students see the project as an essential complement to their primary theoretical training on graduation. Some of them have stated that the practical knowledge they have acquired at high school activities is very different from the theoretical knowledge they have acquired at university.

Many researchers have revealed that there is a distant relationship between professional knowledge and academic knowledge (Schön, 1998; Wideen et al., 1998). According Schön (1998), professional educationists have made clear their concerns about the distance between conceptions about the professional knowledge, that are dominant at universities, and the current skills required of professional in the application field.

The students from PIBID have seen what some researchers have revealed about the practical work. When the pre-service training ends, the students have to work and become teachers, they have to learn about their job at practice, perceiving that sometimes the graduation knowledge are not applicable in practice (Wideen et al., 1998). Schön (1998) emphasizes that when someone learn at practice, is initiated at the traditions of a community of professionals and learn about their conventions, limits, languages, systematic knowledge and patterns in the process of knowing in action. Thus, the PIBID comes as an opportunity to students experiencing the teaching practice, understanding the problems and possibilities of this practice, before becoming a teacher.

Thus, it is emphasized that a good professional instruction of teachers should not be exclusively theoretical, but must involve a certain amount of practical work. According Dewey (1974) the practical work may be conducted with the objective of giving teachers in training working command of the necessary tools of their profession; control of the technique of class instruction and management; skill and proficiency in the work 
of teaching. On the other hand, the practical work can be used as an instrument in making real and vital theoretical instruction; the knowledge of subject-matter and of principles of education.

Also it agrees with Schön (1998) that emphasizes the necessity of students learn to be reflective in the practice to acquire new understandings of uncertain and conflicting situations of practice. Thus, the project PIBID provides an opportunity to students' reflection about the educational condition at our country and acquisition of new understandings about the theory and the practice of teaching chemistry.

\section{Conclusions}

The results indicate that the project PIBID enables the training of pre-service chemistry teacher students to be more consciousness about the teacher's practice, the limits and possibilities of this practice, the necessity to learn to be more reflective in practice to link the theoretical knowledge with the practical knowledge. For the student participants of the chemistry subproject PIBID at USP, this project is an important complement to their training as future teachers, since it enables them to learn at practice. The students could also learn about some education theories, which include visualization theories; they haven't learned in graduation classes and could apply this knowledge in practice.

\section{Acknowledgements}

Acknowledge the scholarship from CAPES, Brazil.

\section{References}

Aksela, M., Lundell, J. (2008). Computer-based molecular modelling: Finnish school teachers' experiences and views. Chemistry Education Research and Practice, 9, 301308.

Barak, M., Ashkar, T., Dori, Y. (2011). Learning Science via animated movies: Its effect on student's thinking and motivation. Computers \& Education, 56 (3), 839-846.

Bardin, L. (1977). Análise de conteúdo. Edições 70: Lisboa.

Barnea, N., \& Dori, Y. J. (2000). Computerized Molecular Modelling- The New Technology for Enhancing Model Perception Among Chemistry Educators and Learns. Research and practice in Europe, 1 (1), 109-120.

Brazil (2012). PIBID: Programa Institucional de Bolsas de Iniciação à Docência. Retrieved January 09, 2013, from http://www.capes.gov.br/educacao-basica/capespibid.

Checkland, P., \& Holwell, S. (1998). Action Research: Its Nature and Validity. Systemic Practice and Action Research, 11 (1), 9-21. 
Chewprecha, T., Gardner, M., \& Sapianchai, N. Comparison of training methods in modifying questioning and wait time behaviour of Thai high school chemistry teachers. Journal of Research in Science Teaching, 17, 191-200.

Chien, Y., Changa, C., Yehc, T., \& Changd, K. (2012). Engaging pre-service science teachers to act as active designers of technology integration: A MAGDAIRE framework. Teaching and Teacher Education, 28, 578-588.

Dewey, J. (1974) The Relation of Theory to Practice in Education, in: R. D. Archambault (Ed.) John Dewey on Education. Chicago, IL: University of Chicago Press, pp. 313 338.

Dori, Y. J., \& Barnea, N. (1997). In-service chemistry teachers' training: the impact of introducing teachers' attitudes and classroom implementation. International Journal of Science, 19 (5), 577-592.

Ferreira, C. R. (2010). O uso de visualizações no ensino de química: A formação inicial do professor de química. (Master's Dissertations São Paulo University, São Paulo) Retrieved January 09, 2013, from http://www.teses.usp.br/teses/disponiveis/81/81132/tde-21022011-161106/pt-br.php.

Hampel, R. (2009). Training teachers for the multimedia age: developing teacher expertise to enhance online learner interaction and collaboration. Innovation in Language Learning and Teaching, 3, 35-50.

Hofstein A., \& Lunetta V.N. (2004). The laboratory in science education: Foundation for the 21 st century, Science Education, 88 (1), 28-54.

Jewitt, C., Kress, G., Ogborn, J., \& Tsatsarelis, C. (2001). Exploring learning through visual, actional and linguistic communication: The multimodal environment of a science classroom. Educational Review, 53 (1), 5-18.

Johnstone, A. H., (1993). The development of chemistry teaching: A changing response to a changing demand. Journal of Chemical Education, 70 (9), 701-705.

Johnstone, A. H., (2000). Teaching of chemistry: Logical or psychological? Chemical Education: Research and Practice in Europe, 1 (1), 9-15.

Justi, R. (2006). La enseñanza de ciencias basada en la elaboración de modelos. Enseñanza de las Ciencias, 24 (2), 173-184.

Savec, V. F. et al. (2006). In-Service and Pre-Service Teachers' Opinion on the Use of Models in Teaching Chemistry. Pedagogical Paper, 53, 381-390.

Schön, D. A. (1991). The reflective turn: Case studies in and on educational practice. New York: Teachers College Press.

Schön, D. A. (1998). Educating the Reflective Practioner Toward a new design for teaching and learning in the professions. Jossey-Bass Inc.

Treagust, D. F., \& Chandrassegaran, A. L. (2009). Instructional Programmer Designed to Enhance Secondary Student's Competence. In: J. K. Gilbert, D. Treagust, J. K. Gilbert, \& D. Treagust (Eds.), Models and Modeling in Science Education: Multiple Representations in Chemical Education (pp. 151-168). Springer: Dordrecht.

Wideen, M., Mayer-Smith, J., \& Moon, B. (1998). A critical analysis of the research on learning to teach: making the case for an ecological perspective on inquiry. Review of Educational Research, 68 (2), 130-178.

Zeichner, K. M. (1993). A Formação Reflexiva de Professores: Idéias e Práticas. Lisboa: Educa. In Gabini, W. S.; \& Diniz, R. E. S. (2009). Formação Continuada de profes- 
sores de química: Uma proposta envolvendo a inserção da informática nas aulas práticas de química. Revista Brasileira de Pesquisa em Educação em Ciências, 9,117.

Received 22 December 2012; accepted 30 February 2013

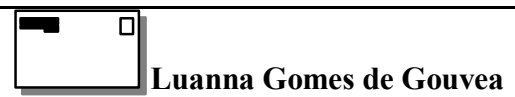

Master Student in Science Education, Faculty of Education, University of Sao Paulo, Sao Paulo, Brazil. E-mail: Luanda.gouvea@yahoo.com.br

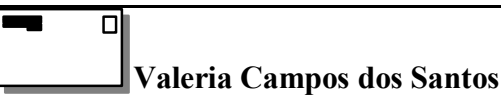

PhD Student in Science Education, Faculty of Education, University of Sao Paulo, Sao Paulo, Brazil. E-mail: valcampos07@hotmail.com

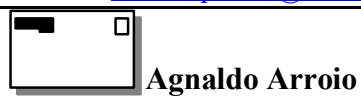

Associate Professor, Faculty of Education, University of Sao Paulo, Sao Paulo, Brazil.

E-mail: agnaldoarroio@yahoo.com

Website: http://usp-br.academia.edu/AgnaldoArroio 